\title{
Optimal salt concentration of vehicle for plasmid DNA enhances gene transfer mediated by electroporation
}

\author{
Min-Jae Lee ${ }^{1, *}$, Soon-Shin Cho ${ }^{1, *}$, Hyung-Suk \\ Jang $^{2}$, Young Shin Lim², Ji-Ran You², Jangwon \\ Park ${ }^{2}$, Hearan Suh', Jeong-a Kim², Jong-Sang \\ Park $^{1}$ and Duk-Kyung Kim ${ }^{2,3}$ \\ ${ }^{1}$ School of Chemistry and Molecular Engineering, Seoul National \\ University, Seoul, Korea \\ ${ }^{2}$ Department of Medicine, Sungkyunkwan University School of \\ Medicine, Samsung Medical Center, Laboratory of Cardiovascular \\ Molecular Therapy, MTRC and SBRI, Seoul, Korea \\ ${ }^{3}$ Corresponding author: Tel, +82-2-3410-3413; \\ Fax, +82-2-3410-3417; E-mail, dkkim@smc.samsung.co.kr \\ *These authors contributed equally to this work.
}

Accepted 22 July 2002

Abbreviations: ICP-AES, inductively coupled plasma-atomic emission spectrometer; IF, low frequency; RLU, relative luminescence unit

\begin{abstract}
In vivo electroporation has emerged as a leading technology for developing nonviral gene therapies, and the various technical parameters governing electroporation efficiency have been optimized by both theoretical and experimental analysis. However, most electroporation parameters focused on the electric conditions and the preferred vehicle for plasmid DNA injections has been normal saline. We hypothesized that salts in vehicle for plasmid DNA must affect the efficiency of DNA transfer because cations would alter ionic atmosphere, ionic strength, and conductivity of their medium. Here, we show that half saline $(71 \mathrm{mM})$ is an optimal vehicle for in vivo electroporation of naked DNA in skeletal muscle. With various salt concentrations, two reporter genes, luciferase and $\beta$-galactosidase were injected intramuscularly under our optimal electric condition (125 V/cm, 4 pulses x 2 times, $50 \mathrm{~ms}, 1 \mathrm{~Hz}$ ). Exact salt concentrations of DNA vehicle were measured by the inductively coupled plasma-atomic emission spectrometer (ICP-AES) and the conductivity change in the tissue induced by the salt in the medium was measured by Low-Frequency (LF) Impedance Analyzer. Luciferase expression increased as cation concentration of vehicle decreased and this result can be visualized by $X$-Gal staining. However, at lower salt concentration, trans-
\end{abstract}

fection efficiency was diminished because the hypoosmotic stress and electrical injury by low conductivity induced myofiber damage. At optimal salt concentration $(71 \mathrm{mM})$, we observed a 3-fold average increase in luciferase expression in comparison with the normal saline condition $(p<0.01)$. These results provide a valuable experimental parameter for in vivo gene therapy mediated by electroporation.

Keywords: electroporation, gene therapy, drug delivery systems, sodium chloride; electric conductivity

\section{Introduction}

Although nonviral gene therapy has several advantages over viral gene transfer (John et al., 2001; Kay et al., 2001; Sun and Frederick, 2001), its transfection efficiency is still low (Templeton and Lasic, 1999; Han et al., 2000; Li and Huang, 2000). Recently, several approaches have been developed to enhance the efficiency of gene transfer and in vivo electroporation has emerged as a leading technology for developing nonviral gene therapies. Its advantages, compared with other nonviral gene delivery systems, are that gene expression is drastically increased (2- to 4-log fold), longlasting (months), and very specific and localized (Mir et al., 1999). This technique has also been successful in various tissues such as skeletal muscle (Muramatsu et al., 1998; Aihara and Miyazaki, 1999; Gehl and Mir, 1999; Imai and Isaka, 1999; Mathiesen, 1999; Rizzuto et al., 1999; Bettan et al., 2000; Lemieux et al., 2000; Maruyama et al., 2000; Vicat et al., 2000; Lucas and Heller, 2001; Muramatsu et al., 2001), liver (Suzuki et al., 1998; Heller et al., 2000), testis (Muramatsu et al., 1997; Yamazaki et al., 1998; Yamazaki et al., 2000), skin (Johnson et al., 1998; Vanbever and Preat, 1999; Glasspool-Malone et al., 2000), cornea (Oshima et al., 1998; Sakamoto et al., 1999), cardiaovascular (Harrison et al., 1998; Martin et al., 2000) and mammary tumor tissue (Goto et al., 2000; Wells et al., 2000; Lohr et al., 2001). In particular, gene delivery to skeletal muscle is a promising strategy for the systemic secretion of therapeutic proteins.

The general mechanism of electroporation starts with an increase in membrane permeability following treatment with electrical pulses and is then followed by influx of DNA through the permeabilized membrane defect (Somiari et al., 2000). Under the influence of an electrical field, the distribution of ions adjacent to the inner surface of cell membranes are believed to be altered, 
resulting in a series of membrane alterations that predispose to pore formation (Neumann et al., 1999). In the transport process, not only passive diffusion but electrophoretic and electroosmotic transport under the influence of electric fields may also facilitate transport of charged molecules and ions across the membranes (Golzio et al., 1998).

Recent reports have demonstrated optimized electroporation conditions including voltage, pulse duration, number of pulse, frequency, DNA concentration, and the amount of injected reporter gene in the tibialis anterior muscle (Golzio et al., 1998; Muramatsu et al., 1998; Gehl and Mir, 1999; Hofmann et al., 1999; Mir et al., 1999; Mekid and Mir, 2000; Miklavcic et al., 2000; Yoshizato et al., 2000; Lucas and Heller, 2001). It was also shown that square-wave electric pulses improve pulsed DNA delivery to living tissues (Mir et al., 1999). In addition, the low voltage-long duration approach maximizes gene delivery and minimizes tissue damage (Muramatsu et al., 1998). Nevertheless hitherto, while most electroporation stu-dies were focused on the electric conditions and electrotransferred DNA, none of these reports have ever compared the effects of vehicles for DNA with electroporation.

We hypothesized that salts in vehicle for plasmid DNA must affect the efficiency of DNA transfer because i) cations in vehicle could diminish electrophoretic and electroosmotic transport of plasmid in an electric field by interaction between cations in vehicle and negatively charged plasmid DNA, and ii) low conductivity at low ionic strength may cause membrane disruption, which leads to cell damage. In this study, we observed the variation of reporter gene expression at various cation concentrations of vehicle for plasmid DNA with our optimal electric parameters. Exact salt concentrations in DNA vehicles were measured by Inductively Coupled Plasma-Atomic Emission Spectrometer (ICP-AES) and the conductivity change in the tissue induced by the salt in the medium was measured by Low-Frequency (LF) Impedance Analyzer. In addition, traditional histological analysis was carried out to determine the transfection efficiency and the degree of cell damage depending on electroporation conditions. Here, we report that half saline is the optimal salt concentration for maximum transfection efficiency and minimum cell damage on in vivo electroporation.

\section{Materials and Methods}

\section{Plasmid DNA preparation}

The firefly luciferase gene and $\beta$-galactosidase gene were used as reporter genes to monitor the gene transfer results. The luciferase expression plasmid ( $\mathrm{pCN}$ -luciferase) and $\beta$-galactosidase expression plasmid (pCN-lacZ) were constructed by subcloning Photinus pyralis luciferase or $E$. coli $\beta$-galactosidase cDNA to pCN, respectively. pCN vector contains the $600 \mathrm{bp}$ HCMV IE promoter and its entire 5-untranslated region consisting of 122 bp exon 1, 827 bp intron 1, and 16 bp exon 2. pCN vector was known to express higher than the vector with only CMV promoter (Lee et al., 2000). Plasmid DNA was transformed into Escherichia coli TOP10 competent cells and plasmid DNA was isolated by plasmid purification Mega kits from Qiagen (Valencia, CA, USA) according to the manufacturers instructions. Plasmids were precipitated in isopropanol. For the first batch of DNA, the above plasmids were resuspended in water and for the second batch of DNA, plasmids were further washed twice with $70 \%$ ethanol and resuspended in water. DNA was stored at $-20^{\circ} \mathrm{C}$ until use.

\section{Measurement of salt concentration by ICP-AES}

Emission measurements of salt concentrations were made with an ICP-AES, Model ICPS-10001V (Shimadzu, Japan).

\section{Intramuscular DNA injection and electroporation in vivo}

All animal experiments were carried out according to the Guideline for the Care and Use of Laboratory Animals published by the US National Institute of Health (NIH Publication No. 85-23, revised 1996). Five-week-old female BALB/c-AnNCrj mouse was anesthetized by intraperi-toneal injection of $100 \mu$ solution consisting of $2.215 \mathrm{mg}$ ketamine (Ketalar $50 \mathrm{mg} / \mathrm{ml}$, Yuhan Co, Korea) mixed with $0.175 \mathrm{mg}$ xylazine (Rompun 23.32 $\mathrm{mg} / \mathrm{ml}$, Bayer, Korea). Fifty microgram DNA in $30 \mu \mathrm{l}$ solution at each salt concentration was injected into the tibialis anterior muscle of the mouse with a 30-gauge insulin syringe (Becton Dickinson, Franklin Lakes, NJ). The syringe needle was fitted with a P10 tube adjusted to settle the depth of needle-tip penetration of a tibialis anterior muscle to $3.0 \mathrm{~mm}$. Thirty seconds after DNA injection, transcutaneous electric pulses using ECM 830 (BTX Division of Genetronics, San Diego, CA) were applied through two electrodes (Tweezertrodes, BTX Division of Genetronics) placed on the surface of the injection site. Electric pulses at $125 \mathrm{~V} / \mathrm{cm}, 50 \mathrm{~ms}$ duration and $1 \mathrm{~Hz}$ were applied four times and a further four times in the reverse direction.

\section{Assay for luciferase activity in vivo}

Unless otherwise stated, mice were humanely killed 7 days after DNA transfer. Tibialis anterior muscles were removed and homogenized in $2 \mathrm{ml}$ of Reporter lysis reagent (Promega, Madison, $\mathrm{WI}$ ). After cen-trifugation at $12,000 \mathrm{rev} . / \mathrm{min}$ for $10 \mathrm{~min}$, luciferase activity was assessed on $10 \mu \mathrm{l}$ of supernatant with a TD-20/20 luminometer (Turner Designs, Sunnyvale, CA). This assessment was made by measuring the in-tegration of 
A

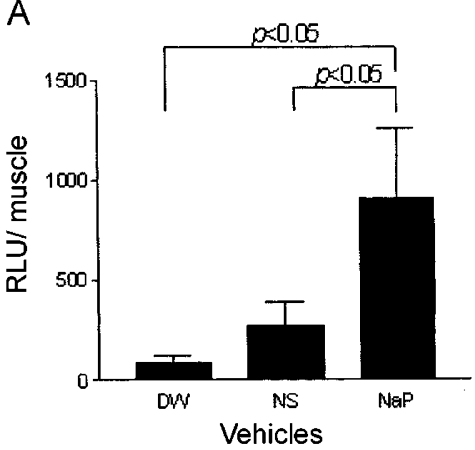

B

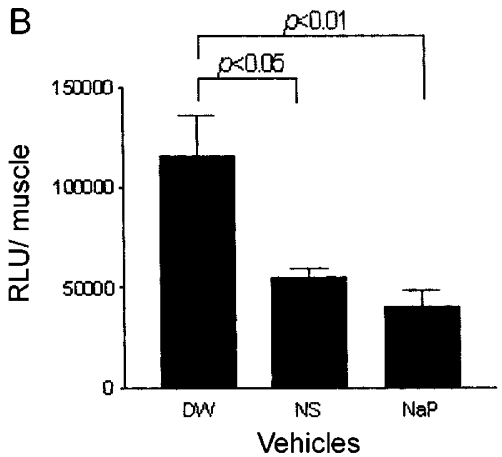

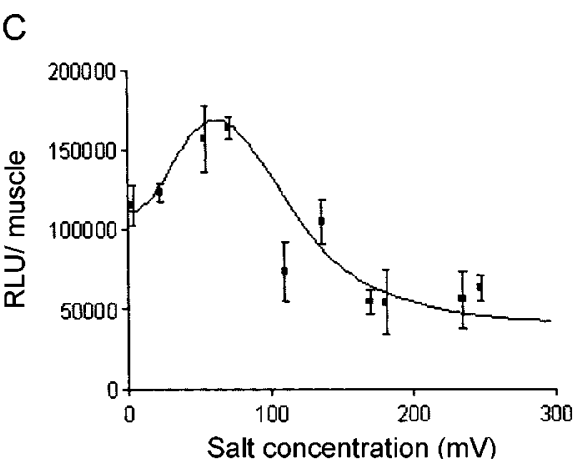

Figure 1. Dependence of luciferase expression on vehicles and on salt concentration in saline. Fifty microgram of pCN-luciferase DNA diluted in $30 \mathrm{ml}$ distilled water, normal saline (150 mM Nacl), and sodium phosphate $(150 \mathrm{mM})$ was injected into mouse tibialis anterior muscle in the absence $(A)$ or presence $(B)$ of electric pulses. Additionally, pCN-luciferase cDNA $(50 \mu \mathrm{g})$ diluted in sterile saline at various concentrations was injected into mouse tibialis anterior muscle with the application of electric pulses (C). Electric pulses were applied $30 \mathrm{~s}$ after DNA injection with our optimal electroporation conditions (125 V/cm, 4 pulses $\times 2$ times, $50 \mathrm{~ms}, 1 \mathrm{~Hz}$ ). The luciferase activity was measured at 7 days after intramuscular injection and exact salt concentrations of DNA vehicle were measured by ICP-AES according to the protocol described in Materials and Methods. Gene expression of distilled water (DW) vehicle was significantly higher than those of NS (normal saline) and NaP (sodium phosphate) by Bonferroni's multiple comparison test $(P<0.01)$ when electric pulses were applied $(\mathrm{B})$. When no electric pulse was applied, these results were radically altered. In this case, NaP vehicle showed the highest transfection efficiency $(A, P<0.05)$ and luciferase activity with distilled water vehicle was about 3 times lower than with normal saline $(P>0.05)$ Moreover, at optimal concentration $(71 \mathrm{mM})$ we observed an average 3 -fold increase in luciferase expression in comparison with normal saline $(P<0.01)(C)$. All data are means \pm SEM of individual values $(n=5$ per each).

the light produced during a period of $30 \mathrm{~s}$, starting $3 \mathrm{~s}$ after the addition of $100 \mu \mathrm{l}$ of luciferase assay substrate (Promega, Madison, WI) to the muscle-fiber lysate.

\section{Histochemical staining for $\beta$-galactosidase activity and analysis of muscle cell damage}

A 5-week-old female BALB/c-AnNCrj mouse was intramuscularly injected with $50 \mathrm{mg}$ of pCN-lacZ in $30 \mu \mathrm{l}$ solution at each salt concentration. One week later, tibialis anterior muscle in the injected mouse was removed and fixed with 4\% paraformaldehyde (Sigma, St. Louis, MO, USA) in phosphate-buffered saline (PBS) for $20 \mathrm{~min}$. This sample was developed in a substrate solution $\left[5 \mathrm{mM} \mathrm{K}_{3} \mathrm{Fe}(\mathrm{CN})_{6}, 5 \mathrm{mM} \mathrm{K}_{4} \mathrm{Fe}(\mathrm{CN})_{6}, 2 \mathrm{mM}\right.$ $\mathrm{MgCl}_{2}, 10 \%$ sodium deoxycholate, NP40 and $50 \mathrm{mg} / \mathrm{ml}$ $\mathrm{X}$-gal in PBS] overnight at $37^{\circ} \mathrm{C}$. To prepare stained tissue cross-sections, tibialis anterior muscle was embedded in OCT (VWR, McGrau Park, IL, USA) and $10 \mathrm{~mm}$ sections were cut using a cryotome (Cryotome AS620, Shandon, UK). Sections were collected on microscopic slides (ProbeOn Plus Microscope Slides, Fisher Scientific, Pittsburgh, PA, USA), brought to room temperature and stained for hematoxylin and eosin (H\&E). A similar protocol, except for the development of b-galactosidase, was observed for quantitative measurement of cell damage on electroporation. In this study, three vehicle systems with and without electric pulses were tested: distilled water $(0 \mathrm{mM} \mathrm{NaCl})$, half saline $(75 \mathrm{mM} \mathrm{NaCl})$ and normal saline $(150 \mathrm{mM} \mathrm{NaCl})$. The percentage of damaged cells was determined by light microscopy in muscle cross-sections. Five representative fields were counted for each slide.

\section{Measurement of impedance parameters in the muscle}

Five-week-old female BALB/c-AnNCrj mice were humanely killed and their tibialis anterior muscles were removed. Two parallel stainless-steel probes holding constant distance (about $6 \mathrm{~mm}$ wide) were inserted into the retrieved muscle and measurements of impedance parameters were carried out by means of LF Impedance Analyzer (model HP 4192A, Hewlett-Packard, Palo Alto, CA, USA) at constant $10 \mathrm{kHz}$ frequency. Ten microliter of normal saline $(150 \mathrm{mM} \mathrm{NaCl})$ or distilled water $(0 \mathrm{mM}$ $\mathrm{NaCl}$ ) was injected by 30 -gauge insulin syringe into the muscle and after $30 \mathrm{~s}$ the changes of the conductivity and resistance were measured.

\section{Statistical analysis of results}

Each condition was tested on at least three different muscles. Results were expressed as the mean (RLU of luciferase per muscle) $)_{ \pm}$SEM. Differences were tested by ANOVA for multiple-sample comparison with Bonferronis posthoc analysis. The level of significance was set at $P<0.05$.

\section{Results and Discussion}

\section{Determination of optimal electroporation para- meters}

In vivo electroporation protocols still lack standardized electrical parameters. Furthermore, the optimum conditions for in vivo electroporation may vary according to tissue, organs, and animal species (Suzuki et al., 1998). 
In order to determine our optimal conditions for in vivo electroporation, we made experiments by varying electrical parameters (data not shown). Maximum transfection efficiency occurred with the following electric conditions: a voltage to distance ratio of $125 \mathrm{~V} / \mathrm{cm}$, a pulse quantity of 8 , a pulse duration of $50 \mathrm{~ms}$, and frequency of $1 \mathrm{~Hz}$. These optimal parameters are supported by similar results in other experiments (Muramatsu et al., 1998; Gehl and Mir, 1999; Mir et al., 1999; Lucas and Heller, 2001).

\section{Comparison of the effect of the three vehicles}

Firstly, we investigated the effects of three vehicles for plasmid DNA in the absence (Figure 1A) or presence (Figure 1B) of electric pulses. The preferred vehicle for naked DNA injections has been normal saline or PBS because these are isotonic, stable, and nontoxic. Recently it was reported that sodium phosphate enhances plasmid DNA expression in vivo possibly by inhibiting DNA degradation (Hartikka et al., 2000). When an electric pulse was not applied (Figure 1A), luciferase activity with distilled water vehicle was about 3 times lower than with normal saline $[87 \pm 36$ versus $269 \pm 115$ relative luminescence unit (RLU) per muscle, $P>0.05$ ] and about 10 times lower than with sodium phosphate $(87 \pm 36$ versus $904 \pm 351$ RLU per muscle, $P<0.05)$. However, this behavior was radically altered in the presence of electric pulses (Figure 1B).

When electric pulses were applied (all experiments have been performed using our optimal electroporation condition; 4 pulses $x 2$ times, $50 \mathrm{~ms}, 8$ pulses, $1 \mathrm{~Hz}$ ), gene expression with distilled water was most efficient when compared with normal saline or sodium phos-phate. With distilled water vehicle, luciferase activity was about 2.1fold higher than with normal saline $(115,200 \pm 20,180$ versus $54,540 \pm 4,746$ RLU per muscle, $P<0.01)$ and about 2.9-fold higher than with sodium phosphate $(115,200 \pm 20,180$ versus $40,190 \pm 8,607$ RLU per muscle, $P<0.001)$.

All vehicles showed an enhancement in transfection efficiency when electric pulses were applied, compared with that in the absence of electric pulses; with distilled water 1,317-fold $(115,200 \pm 20,180$ versus $87 \pm 36 \mathrm{RLU}$ per muscle), with normal saline 203-fold $(54,540 \pm 4,746$ versus $269 \pm 115$ RLU per muscle), and with sodium phosphate 44 -fold $(40,190 \pm 8,607$ versus $904 \pm 351 \mathrm{RLU}$ per muscle). In the case when distilled water vehicle was used, the enhancement of gene transfer by electroporation was the highest.

The mechanism for a reversed pattern of gene expression among different vehicles between the presence and absence of electroporation is not known. We hypothesized that salts in transferred vehicles for plasmid DNA could affect electrophoretic transport of plasmid DNA in an electric field by interaction between cations in vehicle and negatively charged plasmid DNA. This effect was examined in more detail.

\section{Effect of sodium concentration on electroporation}

In order to test our hypothesis, we investigated luciferase gene expression with varying degrees of ionic strength of $\mathrm{NaCl}$ solution. Figure $1 \mathrm{C}$ shows the effect on luciferase activities when various sodium concentrations were used. Exact salt concentrations in saline vehicles were measured by ICP-AES. Column-eluted DNA solution prepared without washing with $70 \%$ ethanol already possessed $23 \mathrm{mM}$ sodium cation. When DNA was washed, practically no sodium cation was detected $(<3 \mathrm{mM})$ and other cations such as potassium were also not detected. Both kinds of DNA were used for different salt concentrations.

Consistent with our hypothesis, luciferase expression increased as cation concentration of vehicle decreased. However, when the ionic strength of $\mathrm{NaCl}$ solution was further decreased below that of half saline, the transfection efficiency was diminished (Figure 1C). At optimal concentration $(71 \mathrm{mM})$ in the presence of electric pulses, we observed an average 3-fold increase of luciferase expression in comparison to normal saline condition $(164,100 \pm 6,550$ versus $54,540 \pm 4,746$ RLU per muscle, $P<0.01)$ and 1.4 fold to distilled water $(164,100 \pm 6,550$ versus $115,200 \pm 20,180$ RLU per muscle, $P>0.05)$.

The decreased gene expression by electroporation at higher salt concentration could be explained by the fact that salt in the DNA vehicle influences gene transfer by altering ionic atmosphere and ionic strength. The basic mechanism of electroporation starts when a direct current electric field of uniform intensity is applied to an organ injected with naked DNA suspended in an aqueous medium. Electroporation causes DNA movement, distorts electric double layer surrounding the DNA, and induces electrical changes at the interfaces (Neumann et al., 1999; Somiari et al., 2000). The presence of ionic atmosphere around the DNA results in electrophoretic mobility slower than those expected when it is in the absence of ionic conditions. Such difference are caused by two effects. First, the potential at the surface of the DNA which dictates the rate of electromigration, is lowered by decreasing the effective electrostatic charge. Second, the electrical field also acts upon the ions surrounding the DNA. As the charge of the ionic cloud is unlike that of the DNA, the cloud will be moved in an opposite to that of the DNA, thus retarding the migration of the latter.

Electrophoretic mobility also decreases with ionic strength. This can be explained by specific binding of certain ions to the DNA by electrostatic interaction. The potential, which determines the rate of electromigration, is the potential at the boundary of the fixed and free liquid. This charge inside this surface determines the 


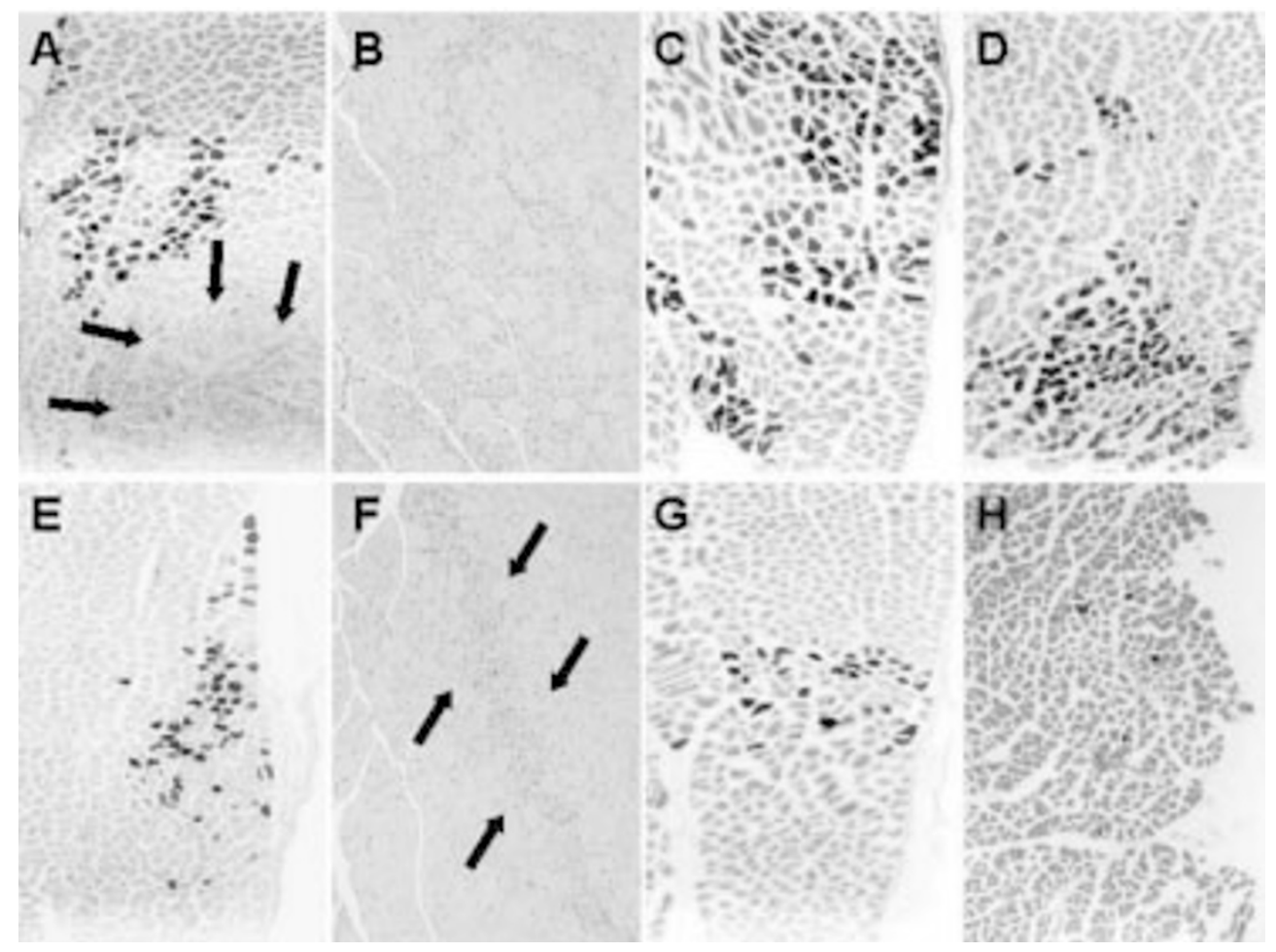

Figure 2. Histochemical staining for $\beta$-galactosidase expression. Fifty microgram of $p C N$-lacZ DNA diluted in sterile saline at various concentrations was injected into mouse tibialis anterior muscle in the presence (A-G: A, B with distilled water; C, with $50 \mathrm{mM} \mathrm{NaCl}$; D, with $100 \mathrm{mM} \mathrm{NaCl}$; $E, F$ with $150 \mathrm{mM} \mathrm{NaCl}, \mathrm{G}$, with $200 \mathrm{mM} \mathrm{NaCl})$ or absence $(\mathrm{H}$, with $150 \mathrm{mM} \mathrm{NaCl})$ of electroporation. After 7 days, X-gal staining was performed as described in Materials and Methods. The pattern of $\beta$-galactosidase expression had very high correlation with the results of luciferase expression (Figure $1 C)$. The arrows in (A) indicate the damaged region. In (B), hematoxylin and eosin stain shows a large area of damage manifested as muscle degeneration, necrosis, infiltration of inflammatory cells or central nucleation. However, in others a minimal area of damaged cells along the track of the needle was observed (arrows in F). Original magnification, $x 25$ $(A, C, D, E, G, H), x 200(B, F)$.

\section{zeta potential.}

However, as the electric strength lowers below certain threshold (i.e., $71 \mathrm{nM}$ of $\mathrm{NaCl}$ in our data), gene expression level decreased unexpectedly. We surmised that this phenomenon was partly due to myocardial damage caused by hypoosmotic vehicle of plasmid DNA.

\section{Histological analysis of $\beta$-galactosidase gene expression and muscle cell damage}

Next, we used the $\beta$-galactosidase plasmid system to see the relationship between cell damage by electroporation and the salt concentration of DNA vehicles. Results are shown in Figure 2. Counting of $\beta$ galactosidase-positive stained fibers showed maximum transfection efficiency in the $50-100 \mathrm{mM}$ concentration range (Figure $2 \mathrm{C}$ and $\mathrm{D}$ ). Only a little staining was observed in the control with no electric pulse (Figure 2H). The pattern of $\beta$-galactosidase expression had a very high correlation with the results of luciferase expression (Figure 1C). Gene expression was limited only in the area where plasmid DNA was injected and it could potentially be a major benefit for electroporation that gene expression is focused on the site where electric pulses are applied. In the distilled water vehicle system, a large area
Table 1. Comparison of cell damage depending on DNA vehicle and electric pulse. The percentage of necrotic cells was determined by light microscopy in muscle cross-sections stained by hematoxylin and eosin. With distilled water in the presence of electroporation, the proportion of damaged cells exceeded $32 \%$, which was significantly higher than those of half saline and normal saline by Bonferroni's multiple comparison test $(P<0.001)$. In half saline with electric pulses, the proportion was around $7 \%$, showing no significant difference from that of normal saline. Data are mean \pm SEM.

\begin{tabular}{lcc}
\hline DNA vehicle & $\begin{array}{c}\text { With electric pulse } \\
(\%)\end{array}$ & $\begin{array}{c}\text { Without electric pulse } \\
(\%)\end{array}$ \\
\hline Distilled water & $32.4 \pm 2.6$ & $<3.0$ \\
Half saline & $6.9 \pm 1.8$ & $<3.0$ \\
Normal saline & $4.7 \pm 1.4$ & $<3.0$ \\
\hline
\end{tabular}

of damage such as muscle degeneration, necrosis, infiltration of inflammatory cells or central nucleation was observed in most mice (Figure 2A and B). However, in other vehicles, a minimal area of damaged cells along the track of the needle was observed (Figure 2F).

In Table 1, when quantitative evaluation of the myofiber damage was carried out in H\&E stained sections of distilled water $(0 \mathrm{mM} \mathrm{NaCl})$, half saline $(75 \mathrm{mM} \mathrm{NaCl})$ and normal saline $(150 \mathrm{mM} \mathrm{NaCl})$ in the presence or 


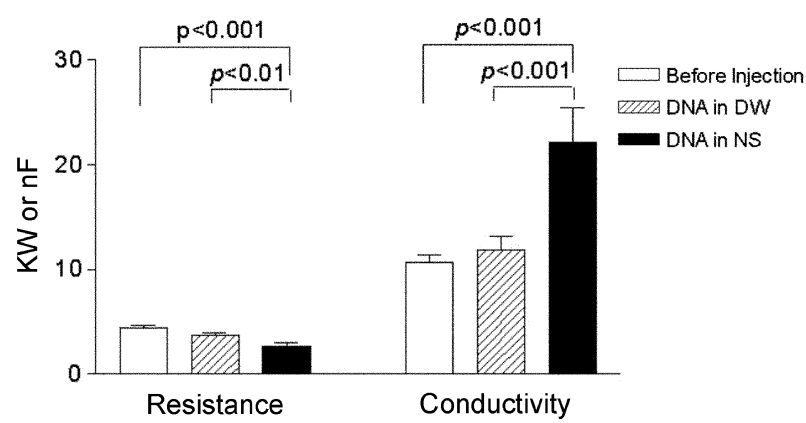

Figure 3. Change of electric parameters in muscle depending on the salt in the medium. Impedance parameters were measured using LF impedance analyzer. Two parallel stainless-steel probes holding constant distance were inserted (about $6 \mathrm{~mm}$ deep) into the retrieved tibialis anterior muscle of BALB/ c-AnNCrj mice and measurements were carried out at constant $10 \mathrm{kHz}$ frequency. Ten microliter of normal saline $(150 \mathrm{mM} \mathrm{NaCl})$ or distilled water $(0$ $\mathrm{mM} \mathrm{NaCl}$ ) was injected by 30-gauge insulin syringe and after $30 \mathrm{~s}$ the change of the conductivity (before injection $10.67 \pm 0.80 \mathrm{nF}$; distilled water $11.90 \pm 1.25$ $\mathrm{nF}$; normal saline $22.20 \pm 3.25 \mathrm{nF}$ ) and resistance (before injection $4.45 \pm 0.18$ $\Omega$; distilled water $3.71 \pm 0.30 \Omega$; normal saline $2.73 \pm 0.29 \Omega$ ) was measured. Figure shows that resistance with distilled water was higher than with normal saline $(P<0.001)$. On the other hand, conductivity with distilled water was lower than with normal saline $(P<0.001)$.

absence of electroporation, no significant damage was detected for any DNA vehicle in the absence of electroporation. On the other hand, when distilled water was used for DNA vehicle in elec-troporation condition, the average percentage of cell damage exceeded $32 \%$. With normal saline, it never exceeded $5 \%$ of the total. And in the case of half saline, there was a similar degree of cell damage to normal saline.

Since muscle damage has been closely associated with reduced gene expression on electroporation (Vicat et al., 2000), it is highly speculative that low ionic strength of vehicle alters its conductivity, increases electrical injury, and then decreases gene expression. Therefore, we have analyzed the change of conductivity depending on different vehicles injected.

\section{Effect of salts in the DNA vehicle on the electric parameters}

Normal saline $(150 \mathrm{mM} \mathrm{NaCl})$ or distilled water $(0 \mathrm{mM}$ $\mathrm{NaCl})$ was injected into the retrieved tibialis anterior muscle, and then electrical resistance and conductivity were measured using low frequency (LF) impedance analyzer. Our results show that resistance with distilled water was higher than with normal saline $(3.71 \pm 0.30$ versus $2.73 \pm 0.29 \Omega, P<0.001$. On the other hand, conductivity with distilled water was lower than with normal saline $(11.90 \pm 1.25$ versus $22.20 \pm 3.25 \mathrm{nF}$, $P<0.001$ ) (Figure 3 ). Under low-conductivity conditions, it has been reported that the electric force contributes significantly to the enlargement of "electroleaks" in the plasma mem-brane generated by electric field (Sukhorukov et al., 1998). This effect presumably results from the transient, conductivity-dependent deformation forces (elongation or compression) on the cell caused by Maxwell stress (Winterhalter and Helfrich, 1998). As ionic strength decreases until certain threshold (i.e., 71 $\mathrm{nM}$ of $\mathrm{NaCl}$ in our data), this electropermeabilization increases gene transfer into the cell. However, below this point, the cell excessively distorted by low conductivity of medium may cause membrane disruption, which leads to cell death. These results indicate that salt in the medium is an important parameter for cell damage after electroporation.

In conclusion, we showed that half saline is an optimal vehicle for in vivo electroporation of naked DNA in skeletal muscle. The average enhancement by this vehicle was about three-fold in comparison to normal saline. Our results support the notion that not only the electromotive forces (i.e., electrophoresis and electroosmosis) but also conductivity of DNA during the electric pulse might be another major factor for electrogenetransfer (Neumann et al., 1999; Somiari et al., 2000) and could provide a valuable experimental parameter for in vivo gene therapy mediated by electroporation. Further study of this mechanism may lead to a better understanding of the electrogenetransfer process.

\section{Acknowledgements}

We thank Dr. Sunyoung Kim for providing $\mathrm{pCN}$, and Dr. Chang-Kyung Kim for giving access to electric equipments. The work was supported by the National Research Laboratory Grants from the Korea Institute of Science and Technology Evaluation and Planning, Korean Ministry of Health and Welfare (01-PJ1-PG101CH06-0003), Science Research Center Grants from Korea Science and Engineering Foundation (DK Kim), the Korea Research Foundation (DP-0344), and the Korea Science and Engineering Foundation (R03-200100031) (JS Park).

\section{References}

Aihara H, Miyazaki Jl. Gene transfer into muscle by electroporation. Nat Biotechnol 1999;16:867-70

Bettan M, Emmanuel F, Darteil R, Caillaud JM, Soubrier F, Delaere P, Branelec D, Mahfoudi A, Duverger N, Scherman D. High-level protein secretion into blood circulation after electric pulse-mediated gene transfer into skeletal muscle. Mol Ther 2000;2:204-10

Gehl J, Mir LM. Determination of optimal parameters for in vivo gene transfer by electroporation, using a rapid in vivo test for cell permeabilization. Biochem Biophys Res Commun 1999;261:377-0

Glasspool-Malone J, Somiari S, Drabick JJ, Malone RW. Efficient nonviral cutaneous transfection. Mol Ther 2000;2:140-6 
Golzio M, Mora M-P, Raynaud C, Delteil C, Teissié J, Rols MP. Control by osmotic pressure of voltage-induced permeabilization and gene transfer in mammalian cells. Biophys J 1998;74:3015-22

Goto T, Nishi T, Tamura T, Dev SB, Takeshima H, Kochi M, Yoshizato K, Kuratsu J, Sakata T, Hofmann GA, Ushio Y. Highly efficient electro-gene therapy of solid tumor by using an expression plasmid for the herpes simplex virus thymidine kinase gene. Proc Natl Acad Sci USA 2000;97:354-9

Han S, Mahato RI, Sung YK, Kim SW. Development of biomaterials for gene therapy. Mol Ther 2000;2:302-17

Harrison RL, Byrne BJ, Tung L. Electroporation-mediated gene transfer in cardiac tissue. FEBS Lett 1998;435:1-5

Hartikka J, Bozoukova V, Jones D, Mahajan R, Wloch MK, Sawdey M, Buchner C, Sukhu L, Barnhart KM, Abai AM, Meek J, Shen N, Manthorpe M. Sodium phosphate enhances plasmid DNA expression in vivo. Gene Ther 2000;7:1171-82

Heller L, Jaroszeski MJ, Coppola D, Pottinger C, Gilbert R, Heller R. Electrically mediated plasmid DNA delivery to hepatocellular carcinomas in vivo. Gene Ther 2000;7:826-9

Hofmann GA, Dev SB, Nanda GS, Rabussay D. Electroporation therapy of solid tumors. Crit Rev Ther Drug Carrier Syst 1999;16:523-69

Imai E, Isaka Y. New paradigm of gene therapy: skeletalmuscle-targeting gene therapy for kidney disease. Nephron 1999;83:296-300

John M Draus, Mary Jane Elliott, Cesar Atienza Jr, Ariel Stilwell, Sandra L Wong, Yanbin Dong, Hailiang Yang, Kelly M. McMasters. p53 gene transfer does not enhance E2F-1mediated apoptosis in human colon cancer cells Exp Mol Med 2001;33:209-19

Johnson PG, Gallo SA, Hui SW, Oseroff AR. A pulsed electric field enhances cutaneous delivery of methylene blue in excised full-thickness porcine skin. J Invest Dermatol 1998; 111:457-63

Kay MA, Glorioso JC, Naldini L. Viral vectors for gene therapy: the art of turning infectious agents into vehicles of therapeutics. Nat Med 2001;7:33-40

Lee Y, Park EJ, Yu SS, Kim DK, Kim S. Improved expression of vascular endothelial growth factor by naked DNA in mouse skeletal muscles implication for gene therapy of ischemic diseases. Biochem Biophys Res Commun 2000;272:230-5

Lemieux P, Guerin N, Paradis G, Proulx R, Chistyakova L, Kabanov A, Alakhov V. A combination of poloxamers increases gene expression of plasmid DNA in skeletal muscle. Gene Ther 2000;7:986-91

Li S, Huang L. Nonviral gene therapy: promises and challenges. Gene Ther 2000;7:31-4

Lohr F, Lo DY, Zaharoff DA, Hu K, Zhang X, Li Y, Zhao Y, Dewhirst MW, Yuan F, Li CY. Effective tumor therapy with plasmid-encoded cytokines combined with in vivo electroporation. Cancer Res 2001;61:3281-4

Lucas ML, Heller R. Immunomodulation by electrically enhanced delivery of plasmid DNA encoding IL-12 to murine skeletal muscle. Mol Ther 2001;3:47-53

Martin JB, Young JL, Benoit JN, Dean DA. Gene transfer to intact mesenteric arteries by electroporation. J Vasc Res 2000;37:372-80

Maruyama $\mathrm{H}$, Sugawa M, Moriguchi $\mathrm{Y}$, Imazeki I, Ishikawa $\mathrm{Y}$, Ataka K, Hasegawa S, Ito Y, Higuchi N, Kazama JJ, Gejyo F, Miyazaki Jl. Continuous erythropoietin delivery by muscletargeted gene transfer using in vivo electroporation. Hum Gene Ther 2000;11:429-37

Mathiesen I. Electropermeabilization of skeletal muscle enhances gene transfer in vivo. Gene Ther 1999;6:508-14

Mekid $\mathrm{H}$, Mir LM. In vivo cell electrofusion. Biochim Biophys Acta 2000;1524:118-30

Miklavcic D, Semrov D, Mekid H, Mir LM. A validated model of in vivo electric field distribution in tissues for electrochemotherapy and for DNA electrotransfer for gene therapy. Biochim Biophys Acta 2000;1519:73-83

Mir LM, Bureau MF, Gehl J, Rangara R, Rouy D, Caillaud JM, Delaere P, Branellec D, Schwartz B, Scherman D. Highefficiency gene transfer into skeletal muscle mediated by electric pulses. Proc Natl Acad Sci USA 1999;96:4262-7

Muramatsu T, Shibata O, Ryoki S, Ohmori Y, Okumura J. Foreign gene expression in the mouse testis by localized in vivo gene transfer. Biochem Biophys Res Commun $1997 ; 233: 45-9$

Muramatsu T, Nakamura A, Park HM. In vivo electroporation: a powerful and convenient means of nonviral gene transfer to tissues of living animals. Int J Mol Med 1998;1:55-62

Muramatsu T, Arakawa S, Fukazawa K, Fujiwara Y, Yoshida T, Sasaki R, Masuda S, Park HM. In vivo gene electroporation in skeletal muscle with special reference to the duration of gene expression. Int J Mol Med 2001;7:37-42

Neumann E, Kakorin S, Tœnsing K. Fundamental of electroporative delivery of drugs and genes. Bioelectrochem Bioenerg 1999;48:3-16

Oshima Y, Sakamoto T, Yamanaka I, Nishi T, Ishibashi T, Inomata $\mathrm{H}$. Targeted gene transfer to corneal endothelium in vivo by electric pulse. Gene Ther 1998;5:1347-54

Rizzuto G, Cappelletti M, Maione D, Savino R, Lazzaro D, Costa P, Mathiesen I, Cortese R, Ciliberto G, Laufer R, La Monica N, Fattori E. Efficient and regulated erythropoietin production by naked DNA injection and muscle electroporation. Proc Natl Acad Sci USA 1999;96:6417-22

Sakamoto T, Oshima Y, Nakagawa K, Ishibashi T, Inomata H, Sueishi K. Target gene transfer of tissue plasminogen activator to cornea by electric pulse inhibits intracameral fibrin formation and corneal cloudiness. Hum Gene Ther 1999;10: 2551-7

Somiari S, Glasspool-Malone J, Drabick JJ, Gilbert RA, Heller $\mathrm{R}$, Jaroszeski MJ, Malone RW. Theory and in vivo application of electroporative gene delivery. Mol Ther 2000;2:178-87

Sukhorukov VL, Mussauer H, Zimmermann U. The effects of electrical deformation forces on the electropermeabilization of erythrocyte membranes in low- and high-conductivity media. $J$ 
Membrane Biol 1998;163:235-45

Sun U Song, Frederick M Boyce. Combination treatment for osteosarcoma with baculoviral vector mediated gene therapy (p53) and chemotherapy (adriamycin) Exp Mol Med 2001;33: 46-53

Suzuki T, Shin BC, Fujikura K, Matsuzaki T, Takata K. Direct gene tranfer into rat liver cells by in vivo electroporation. FEBS Lett 1998;425:436-40

Templeton NS, Lasic DD. New directions in liposome gene delivery. Mol Biotechnol 1999;11:175-80

Vanbever R, Preat VV. In vivo efficacy and safety of skin electroporation. Adv Drug Deliv Rev 1999;35:77-88

Vicat JM, Boisseau S, Jourdes P, Laine M, Wion D, BoualiBenazzouz R, Benabid AL, Berger F. Muscle Transfection by electroporation with high-voltage and short-pulse currents provides high-level and long-lasting gene expression. Hum Gene Ther 2000;11:909-16
Wells JM, Li LH, Sen A, Jahreis GP, Hui SW. Electroporationenhanced gene delivery in mammary tumors. Gene Ther 2000;7:541-7

Winterhalter M, Helfrich W. Deformation of Spherical vesicles by electric fields. J Colloid Interf Sci 1988;122:583-6

Yamazaki Y, Fujimoto H, Ando H, Ohyama T, Hirota Y, Noce T. In vivo gene transfer to mouse spermatogenic cells by deoxyribonucleic acid injection into seminiferous tubules and subsequent electroporation. Biol Reprod 1998;59:1439-44

Yamazaki Y, Yagi T, Ozaki T, Imoto K. In vivo gene transfer to mouse spermatogenic cells using green fluorescent protein as a marker. J Exp Zool 2000;286:212-8

Yoshizato K, Nishi T, Goto T, Dev SB, Takeshima H, Kino T, Tada K, Kimura T, Shiraishi S, Kochi M, Kuratsu Jl, Hofmann GA, Ushio Y. Gene delivery with optimized electroporation parameters shows potential for treatment of gliomas. Int $\mathrm{J}$ Oncol 2000;16:899-905 